This is a self-archived version of an original article. This version may differ from the original in pagination and typographic details.

Author(s): Fingerroos, Outi

Title: Evakkomatka lasten ja muistitietotutkijan silmin

Year: 2015

Version: Published version

Copyright: (c) Kirjoittaja \& Suomen Kansantietouden Tutkijain Seura, 2015

Rights: In Copyright

Rights url: http://rightsstatements.org/page/lnc/1.0/?language=en

Please cite the original version:

Fingerroos, O. (2015). Evakkomatka lasten ja muistitietotutkijan silmin. Elore, 22(1).

https://doi.org/10.30666/elore.79197 


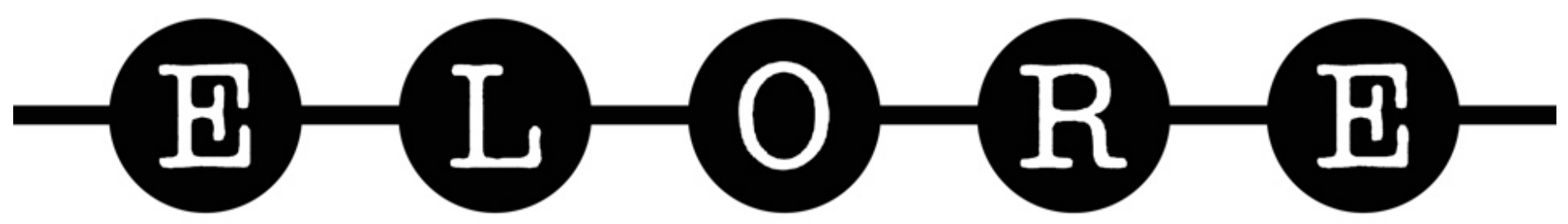

\section{EVAKKOMATKA LASTEN JA MUISTITIETOTUTKIJAN}

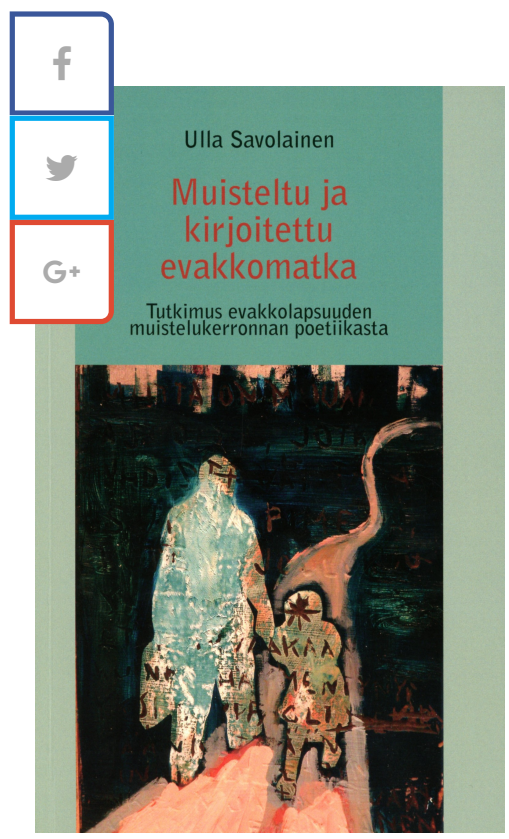

\section{Savolainen, Ulla 2015: Muisteltu ja kirjoitettu evak evakkolapsuuden muistelukerronnan poetiikasta. J Kansantietouden Tutkijain Seura. 414 sivua.}

Outi Fingerroos

Ulla Savolaisen folkloristiikan alan väitöskirja Muisteltu ja kirjoitettu evakkomatk muistelukerronnan poetiikasta (2015) on muistitietotutkimus siirtokarjalaisten la Lähdeaineistona ovat Karjalan Liiton vuonna 2004 toteuttaman Lasten evakkoma Savolainen nimittää lapsievakkojen muistelukirjoituksiksi. Aineistojen äärellä Sav rupeaman. Työ alkoi vuonna 2005, kun hän suoritti folkloristiikan arkistopraktik Liitossa. Hän sai työtehtäväkseen järjestellä tuoreen keruun vastauksia arkistoinı

Tutkimus edustaa monografiamuotoisten väitöskirjojen kunniakkainta kaartia. Se on perusteellinen ja laaja. Sivu Rakenne on neliosainen: johdannossa käydään läpi tutkimuksen lähtökohdat, kontekstit, aineistot ja metodolog yhtään kiveä ei ole jätetty kääntämättä. Johdannosta edetään itse "pihviin" eli kerronnan rakenteen ja temporaali muistelun materiaalisuuden, kehollisuuden ja sosiaalisuuden ilmentymiin (Osa III). Aineistoja Savolainen lukee tá päättyy yhteenvetoon (Osa IV).

\section{Tutkimuksen paikka}

Tutkimuksen paikka on ensisijaisesti muistitietotutkimuksessa (oral history-liike) ja folkloristisessa kerronnant। tutkimuksessa hyvin vahvasti kohde, jota käytännössä tarkastellaan folkloristisena muistelukerrontana. Narratiiv asenne, jossa kertomuksia pidetään abstrakteina ja arvolatautuneina kulttuurisina kehyksinä, sosiaalisten ja kulı ja neuvotteluna (erit. hallitsevat kertomukset ja vastakertomukset). Narratologiaa hyödynnetään, kun tarkastella

Lapsievakkojen muistelukirjoitukset ovat kirjoitettua kerrontaa, jolla kuitenkin on yhtymäkohtia puhuttuun kiele on evakkolasten oman menneisyyden ja historian tulkintaa ja luonteeltaan dialogista. Lapsievakot kertovat kodir siitä, miten evakkomatka on jäsentänyt heidän koko elämäänsä. On olemassa aika ennen ja jälkeen evakkomatk. 
Muisteluaineistot viittaavat aina todellisiin menneisyyden tapahtumiin, joille lapsievakot antavat omia merkityksi kokemuksistaan ylpeästi: he pitävät muistojaan kertomisen arvoisena ja hyödyntävät ilmaisussa erilaisia kerronr teksteissä myös henkilökohtaisia kokemuksiaan, muistojaan ja näkemyksiään, mutta tekevät sen keruun teemar silmällä pitäen. Kirjoitusten referentiaalisuuden aste riippuukin siitä, minkälaisia merkityksiä kirjoittajat liittävät hetkeen. Lisäksi muistelukirjoituksilla on retrospektiivinen ja omaelämäkerrallinen luonne. Kerrontahetki on aini tekstien menneisyydet ovat kerroksellisia.

Savolaisen tutkimuksen teoreettinen kehys on valtava. Edellä esiteltyjen näkökulmien lisäksi hän käsittelee muis analyysin apuvälineitä tuodaan kulttuurisen muistitutkimuksen alueelta (cultural memory studies -tutkimus). Ke johdattanut Savolaisen vertaamaan niitä Bahtinin tulkintoihin genreistä. "Monimutkaisena genrenä muistelukirjo genrejen kokoelma vaan pikemminkin genrejen kollaasi", toteaa Savolainen (s. 87).

\section{Muistelun tavoitteet ja strategiat}

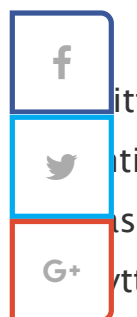

ittaen kertovat evakot ovat Savolaisen tulkinnassa (Osa II) yksilöitä, joista jokaisella on oma erityinen evakkı tionsa ja kerrontastrategiansa. Savolainen jaottelee kerrontastrategiat kolmeen tyyppiin. Totuus- ja historic stelevat menneisyyttä etäisyyden takaa ja pyrkivät kuvaamaan sen mahdollisimman totuudenmukaisesti, et

ttäen. Refleksiivinen kerrontastrategia on otteeltaan subjektiivisempaa. Kirjoittajat eläytyvät, ovat avoimia j löytääkin strategiasta yhtymäkohdan yksilön merkitystä korostaviin psykososiaalisiin diskursseihin: kirjoittajat e psykoanalyyttista sanastoa ja osaavat kirjoittaa pelottavista kokemuksista ja sotatraumoista osuvin sanankäänte kerrontastrategia puolestaan hyödyntää fiktionaalisuuden retoriikkaa, mikä tarkoittaa, että tekstit ovat vivahteik leikitteleviä. Tyypillistä myös on, että kertojat kirjoittavat menneisyyden preesensissä, mikä lähentää lukijaa mui kerronnan retoristen funktioiden, kuten murteen, menneisyyden preesensin ja lapseuden poetiikan käyttö on jol dramatisoitumiseen (performatiivisuus).

Savolainen kuitenkin muistuttaa, että muistelukirjoituksissa eri kerrontastrategiat eivät ole toisiaan poissulkevia evakkomatkakirjoituksia luonnehtivia ominaispiirteitä. Hän rakentaa yhtymäkohdan Bahtin-piirin genreteoriaan, limittäisinä ja rajoiltaan sumeina. Savolainen kuitenkin irrottautuu suoranaisesta bahtinilaisuudesta todetessaan muistelukerronnassa kerronnan strategiat eivät noin vain täytä Bahtinin genreteorian tunnusmerkkejä vaan pike käytänteitä. Kirjoittajien intentioita voi käytännössä lukea esimerkiksi saatekirjeistä, joissa he usein antavat suor

\section{Muistelun materiaalisuus, kehollisuus ja sosiaalisuus}

Tutkimuksen kolmas osa rakentuu muistin paikkojen ympärille. Muistin paikat ovat Savolaisen määrittelyssä elet materiaalisia, kehollisia ja kerronnallisia solmukohtia. Tarkempaan analyysiin Savolainen nostaa muun muassa $n$ metonyyminen yhteys menetettyyn kotipaikkaan ja aikaan. Myös nimeäminen on eräs muistin paikan ulottuvuus menneisyyden olemassaolosta, ja nimeäminen on kiinnittymistä ja muistelijan oman minuuden rakentamista. Yli analyysissä, että lapsievakkojen muistelukirjoittaminen on korjaavaa, muokkaavaa ja hajottavaa toimintaa.

Myös matkan tekemiseen, ylirajaisuuteen ja toiseuteen liittyvät keskustelut ovat antoisia - jopa niin, että rajanyli ihmiselämän taitekohtien metaforina. On kiinnostavaa, että rituaaliteoriasta nousevat ilmaukset pyhiinvaelluksis liminaalisuudesta ovat Savolaisenkin analyysissa niin keskeisiä. Evakkomatka on jälleen kerran siirtymärituaali ir ja erilaisten tila-paikkojen kohtaamisineen. Erinomaisena löytönä pidän sitä, että aistien maailma on lapsievakoi Muistelukirjoituksissa toistuvat tuttujen makujen, tuoksujen ja kokonaisten aikakausien kuvaukset. Toisaalta tel tekee niistä pelon kyllästämiä, surullisia ja traagisia todistuskertomuksia lapsista toisen maailmansodan uhreina 


\section{Yhteenveto}

Lasten kokeman evakkouden, pelon, vierauden ja toiseuden kokemukset ovat teema, josta tutkimusta on toistai Savolainen kirjoittaakin tutkimuksensa lopussa, että "viime vuosikymmeniin asti evakkomatkaa ja Karjalan mene niiden tutkimus on painottunut aikuisten näkökulmaan" (s. 322). Siksi Savolaisen tutkimusta voi pitää tärkeänä tutkimuksessa että uuden sotahistorian ja ylirajaisen muuttoliikkeen tutkimuksessa. Ennen kaikkea tutkimus tot ideologiaa: keskiössä ovat tavallisten ihmisten, unohdettujen ja vaiettujen omat menneisyyden tulkinnat.

Jufojen ja tehokkuuden aikakaudella on ilo lukea kunnolla tehtyä ja raportoitua humanistista perustutkimusta. E se paneutuu lapsievakkojen kirjoittaen kertomaan muisteluun ja diasporan kokemuksen erityisyyteen teoreettis tutkimusta ei ole kirjoitettu, mutta tutkijayhteisölle se on erittäin painava puheenvuoro.

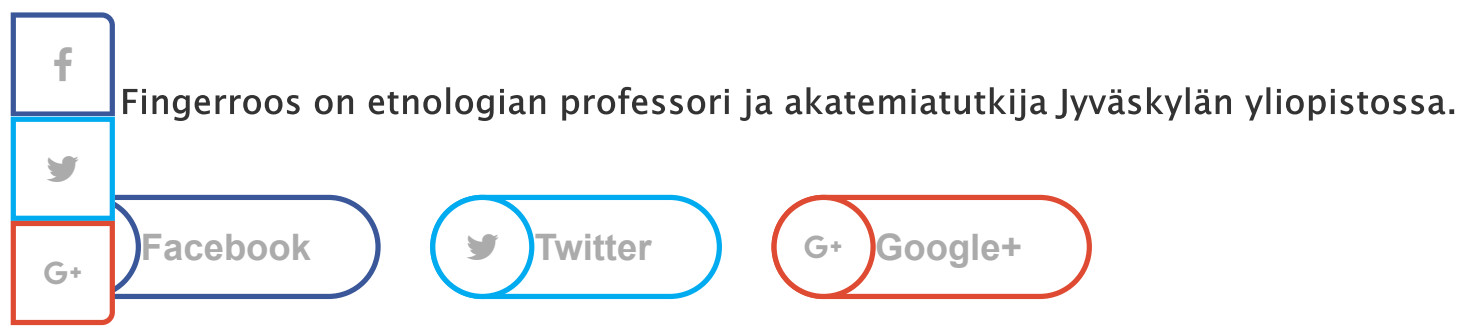

Posted in Elore 1/2015, Kirja-arviot on 5.6.2015.

Elore (ISSN 1456-3010) on tiettävästi

Suomen vanhin vapaan saatavuuden verkkolehti. Elorea julkaisee Suomen Kansantietouden Tutkijain Seura ry.

Logo: Jokke Saharinen

Taitto: Petja Kauppi, Tekstihuoltamo

Kielentarkastus (engl.): Tiina Mällo

Eloren sivuston kopioiminen on kielletty ilman päätoimittajan ja Kansantietouden

Tutkijain Seuran lupaa. 
Viitattaessa julkaisun teksteihin lähteenä

mainitaan Elore ja viittaus tehdään

artikkelin URL-osoitteeseen.

Tätä julkaisua saa tulostaa ja valokopioida muuhun kuin yksityiseen käyttöön edellyttäen, että teoksen käytöstä vastaavalla organisaatiolla on voimassa valokopiointisopimus tekijänoikeusjärjestö Kopioston kanssa.

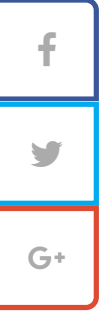

